\title{
A Typical Politician vs. a Lunatic Businessman: Different Language Styles of Hillary Clinton and Donald Trump
}

\author{
Yuqing Zhao ${ }^{1}$, Ting $\mathrm{Wu}^{1} \&$ Huiyu Zhang ${ }^{1}$ \\ ${ }^{1}$ Department of Linguistics and Translation, Zhejiang University, Hangzhou, China \\ Correspondence: Huiyu Zhang, Department of Linguistics and Translation, School of International Studies, \\ Zhejiang University, Hangzhou, 310058, China. E-mail: zhanghuiyu@zju.edu.cn
}

Received: November 23, 2019 Accepted: December 28, 2019 Online Published: January 18, 2020

doi:10.5539/ijel.v10n2p26

URL: https://doi.org/10.5539/ijel.v10n2p26

\begin{abstract}
The victory of Donald Trump over Hillary Clinton in the 2016 US election shocked the media and the public around the world. In an attempt to understand the linguistic differences between Clinton and Trump that might explain the unexpected result, both quantitative and qualitative methods were used in the research to analyze their particular language features in the speeches and different strategies employed in their debates. The quantitative result showed that Trump's language was not as rich as Clinton's. And in terms of the qualitative analysis, it was found that Clinton tended to use the pronoun you more than Trump and that both of them were inclined to make frequent use of we in their campaign speeches. As for debate strategies, Trump, compared with Clinton, was more likely to interrupt and repeat for the purpose of showing power and leaving the audience a stronger impression. The research offers insights into Trump's and Clinton's linguistic features and debate strategies that might account for Trump's victory in the election.
\end{abstract}

Keywords: Donald Trump, Hillary Clinton, linguistic features, political discourse, quantitative and qualitative analysis

\section{Introduction}

Almost three years into Trump's presidency, the world has witnessed many of his surprising moves, including dropping out of the Trans-Pacific Partnership Agreement (TPP) on trade and the Paris Agreement on climate change, issuing a ban on immigrants from some Muslim countries, and implementing increasing trade tariffs on other countries. His surprising policies can be a very long list. What Trump has done in the past years is a reflection of the fact that he started to abandon America's old tradition of being a global sheriff. Instead, he started to increasingly focus on the interests of America. "Making America Great Again" was exactly the slogan that Trump used during the 2016 US election, helping him win the support of a large number of voters. The approaching 2020 United States presidential election again reminds us of the unexpected victory of Donald Trump in the 2016 US election. In the meantime, as a seasoned politician, Hillary Clinton, the other presidential candidate in the 2016 election, was expected to win by most of the media and the public around the world. The election result, however, was just the opposite, rendering people confused and making them wonder about the reasons behind the unforeseen outcome.

In the wake of it, a range of perspectives have been provided to account for the stunning victory of Trump. Some scholars have connected his success to racial and sexual factors (Major, Blodorn, \& Major Blascovich, 2018; Lajevardi \& Abrajano, 2019; Bock, Byrd-Craven, \& Burkley, 2017; Bracic, Israel-Trummel, \& Shortle, 2019; Philpot, 2018). For instance, white voters' concerns about their racial identity, anti-Muslim sentiment in the US, sexist attitudes towards women, and the racial factor in the gender gap (Major, Blodorn, \& Major Blascovich, 2018; Lajevardi \& Abrajano, 2019; Bock, Byrd-Craven, \& Burkley, 2017; Bracic, Israel-Trummel, \& Shortle, 2019; Philpot, 2018) all contributed to Trump's victory. Additionally, other factors such as economic dissatisfaction, social problems, religious beliefs, and voters' trust have been believed to serve as predictors for supporting Trump as well (Monnat \& Brown, 2017; Franco, 2016; Whitehead, Perry, \& Baker, 2018; Shockley-Zalabak, Morreale, \& Stavrositu, 2019). These studies mostly explore the issue from a sociological or psychological perspective, analyzing external factors that are related to economy, society, and most importantly, the potential voters. The internal factors of the two presidential candidates, however, have not been thoroughly examined. 
Hence, this paper focuses on the two candidates to analyze some potential reasons. Since a huge amount of speeches and debates are involved in presidential campaigns, language is a key element during the election period. Many researchers have actually identified that language is a powerful weapon for the success of many politicians (Tenorio, 2002; Ricks, 2018; Ernst, Esser, Blassnig, \& Engesser, 2019). In view of that, the research aims to compare the two candidates' language styles to dig out the secret of Trump's incredible victory over Clinton. By looking into different language features of the two candidates and how they employed language during the election period, it is expected that, from a linguistic view, some possible explanations for Trump's victory can be found. In this research, both quantitative and qualitative methods are used to examine the similarities and differences in the speech language and the debate performance of Clinton and Trump. With the help of statistics and the theory of critical discourse analysis (henceforth CDA), "the subjective nature of the qualitative analysis" (Abbas, 2019, p. 505), to some extent, is expected to be overcome.

Overall, this study attempts to address the following two questions:

1) What are the linguistic features in Clinton's and Trump's speeches, and what strategies were used in their debates?

2) How could the linguistic features in Clinton's and Trump's speeches, and their debate strategies affect the election outcome?

\section{Literature Review}

\subsection{Campaign Language and Debate Strategies}

When it comes to individual factors of the two candidates, their language has been a topic of interest for many scholars. For example, Savoy (2018) examined the style and rhetoric of Clinton and Trump in terms of both oral and written forms. His work pinpointed a bigger difference shown in the two forms for Trump and a fact that Trump tended to be more direct than Clinton. A similar finding was provided by Edward, Hutahaean, Kurniawan, and Hamuddin (2018). They examined the relationship between language and power by investigating speech acts of Clinton and Trump during the 2016 presidential debate. The results identified that Trump seemed to be more directive while Clinton was more indirect. Language of the two candidates also revealed gender differences. In Grebelsky-Lichtman's and Katz's (2019) research, both verbal and nonverbal languages were analyzed, which revealed that Clinton and Trump presented themselves as in line with their gender features and that nonverbal language was under a bigger influence of gender.

Besides language, abundant studies have also focused on debate strategies of the presidential candidates. Specifically speaking, Jacobsen (2019) analyzed interruptions during the first 2016 US presidential debate, and provided an explanation as to why Trump was viewed as the one that interrupted frequently. Quam and Ryshina-Pankova (2016) reviewed patterns of interaction with voters in the campaign speeches of three candidates, namely, Trump, Clinton and Sanders. By employing the Engagement framework, it was shown that Trump differed from the other two more mainstream politicians in terms of strategy use. By analyzing Clinton's and Trump's speech themes and discourse strategies, Liu and Lei (2018) found that Clinton was more likely to appeal to reason while Trump attempted to appeal to negative sentiments during 2016 election campaigns. The above studies have offered insights into the two candidates' language features and strategies, but only a few of them conducted their research from a linguistic perspective (e.g., Liu \& Lei, 2018; Savoy, 2018).

\subsection{Speeches and Debates as Political Discourse}

Numerous studies have concentrated on the analysis of political discourse such as political speeches and political debates. In terms of research subjects, many researchers laid emphasis on the speeches of political leaders (Sharififar \& Rahimi, 2015; Borriello, 2017; Carreon \& Svetanant, 2017; Alemi, Latifi, \& Nematzadeh, 2018). As for research content, gender issues in political settings (Vasvári, 2013; Dicu, 2018; Petlyuchenko \& Charnyakova, 2019), strategies and tactics such as silence to realize political goals (Alagözlü \& Sahin, 2011; Ponomarenko, Vasilkova, Volskaya, Kasperova, \& Nikolaeva, 2018; Alemi, Latifi, \& Nematzadeh, 2018), and techniques like irony, metaphors, and the use of hyperboles, acclaims, attacks and defenses in political speeches and debates (Benoit \& Sheafer, 2006; Nuolijärvi \& Tiittula, 2011; Linkeviciute, 2019; Abbas, 2019) are among the themes of interest for many scholars. After the 2016 election, the whole world had its eyes on the new president of the United States. Extensive literature has investigated Trump's speeches, debates, and his tweets on social media. For example, the element of populism was found in Trump's discourse (Chilton, 2017; Montgomery, 2017; Demata, 2017). Moreover, Trump's controversial comments on racism, immigration and Islamophobia have also been topics of interest (Terrill, 2017; Demata, 2017; Waikar, 2018). Apart from that, many scholars have directed their attention beyond Trump, providing an overview of Trump's uniqueness from 
other US politicians in the 2016 election. Among them, Wang and Liu (2018) looked into changes of stylistic features of Donald Trump over time and his differences from other politicians. Other comparative studies were also conducted. For instance, Aswad (2019) demonstrated that Trump tended to use more hyperbolic crisis rhetoric while Clinton was more likely to employ egalitarian rhetoric. By analyzing speeches of Trump, Clinton and Sanders, Schoor (2017) asserted that these three US politicians presented different political styles in terms of ideology. Trump possessed a populist style, Sanders a populist-pluralist style while Clinton an elitist-pluralist style.

Nevertheless, these studies mostly investigated the overall features of the candidates' language without a focal point on some specific details. In an attempt to further narrow down their language features, this research attempts to focus on pronouns in campaign speeches to illustrate linguistic similarities and differences of Clinton and Trump with the combination of quantitative and qualitative analysis.

\subsection{Critical Discourse Analysis (CDA)}

Additionally, among the above studies, many of them utilize linguistic theories and measures as their main research method, of which CDA is a frequently used one (e.g., Sharififar \& Rahimi, 2015; Carreon \& Svetanant, 2017; Wang \& Liu, 2018). CDA entails applying "discourse analytic techniques" "to interrogate social phenomena" with the combination of "a critical perspective" (Ainsworth \& Hardy, 2004, p. 236). As a kind of discourse analysis, it is used to analyze the text so that the underlying assumptions and ideologies can be drawn from the text. Considered as a common way to comprehend and explain the world (Kelsey, 2003), discourse can, to some extent, reflect the reality of the world. Besides, one of the goals of CDA is to make hidden messages explicit by a detailed analysis of small linguistic features (Hardy, 2008) or the overall structure of a discourse. CDA is also designed for detecting links "between language and other elements" (Fairclough, 2001, p. 230) in our life. Thus, the application of CDA in the analysis of discourse can shed light on the real world, allowing people to see what is hidden beneath the superficial expressions of words and phrases. Furthermore, albeit CDA has been used as a common theory in textual analysis, it has also received some criticism during its development. Some critics have accused it of choosing merely a limited quantity of discourses (Sriwimon \& Zilli, 2017) and of "the imminent risk of "cherry picking"" (Törnberg \& Törnberg, 2016, p. 134), which means that a single text is selected to demonstrate the author's opinion. Thus, the above disapproval raises doubts about the representativeness of the target texts and the problem of overgeneralization. Nevertheless, solutions can be found to minimize its disadvantages, that is, the utilization of quantitative analysis.

\section{Methods}

\subsection{Data}

Our corpus is a self-constructed one with speech and debate transcripts of Hillary Clinton and Donald Trump, which are downloaded from online sources. The specific information is listed in the Appendix.

In all, 20 speech transcripts are collected - 10 of them are Clinton's campaign speeches and another 10 are Trump's. Additionally, three transcripts for the TV debates between Clinton and Trump are also included. The distribution of the corpus is shown in Table 1.

Table 1. The distribution of the transcripts

\begin{tabular}{lll}
\hline & Clinton & Trump \\
\hline Presidential debates & 3 & 3 \\
Campaign speeches & 10 & 10 \\
Total & 13 & 13 \\
\hline
\end{tabular}

\subsection{Data Processing and Analysis}

Both quantitative and qualitative methods were applied in the research. For quantitative measures, two tools were used to process the data collected. One was QUITA (Quantitative Index Text Analyzer) and the other was AntConc 3.4.4w (Windows) 2014. QUITA is mainly used for calculating quantitative indexes that are related to frequency and distribution (Liu, 2017, p. 133), and AntConc is a corpus analysis toolkit for concordance and text analysis. Before using the two tools, the debating contents of Clinton and Trump were separated into two different files and the contents of irrelevant speakers were excluded. By employing the software QUITA, vocabulary richness can be calculated and this index is represented by the value of $R_{l}$. By applying AntConc, keyword lists for the 20 speeches of the two 2016 presidential candidates (10 for each) and their debates ( 3 files 
for each) were generated respectively. First, we imported a target corpus, Trump's speech transcripts for example, into the software. Second, we used the "Keyword List" in the "Tool Preferences" to generate the keyword lists of the corpus. We used the "BNC-Wordlist", "BNC-Written Wordlist" and "BNC-Spoken Wordlist" as our reference corpus. Last, a table of the keyword list was generated. The same steps were taken to process the other three target corpora, namely, Hillary's speech transcripts, Trump's debate transcripts, and Hillary's debate transcripts. For qualitative methods, the theory of CDA is employed. According to van Dijk (2015, p. 478), CDA has particularly concentrated on political discourses in that it takes a special interest "in the critical study of power abuse". Political discourse can refer to a variety of oral or written discourses that are different in kinds, including "a speech, debate, political interview, policy document" (Wilson, 2015, p. 775), etc. As speech and debate transcripts, the data collected for the research are one type of the political discourses that CDA deals with. By analyzing the keywords, the collocations, and their links to other factors in society, the research intends to figure out the hidden messages in the speeches and debates of Donald Trump and Hillary Clinton. With the combination of quantitative and qualitative methods, both a broad picture and the details can be illustrated in the research.

\section{Results and Discussion}

\subsection{A General View}

Through the analysis by QUITA, the result can be seen in Table 2 .

Table 2. Quantitative results for the texts

\begin{tabular}{llllll}
\hline Text & Types & Tokens & TTR & $H$-point & $R_{l}$ \\
\hline Clinton's speeches & 3983 & 38735 & 0.102827 & 80.5 & 0.549713 \\
Trump's speeches & 3908 & 38919 & 0.100414 & 76.5 & 0.561811 \\
Clinton's debates & 2285 & 18403 & 0.124165 & 54.6667 & 0.566876 \\
Trump's debates & 2001 & 23190 & 0.086287 & 65 & 0.531156 \\
\hline
\end{tabular}

\subsubsection{TTR}

TTR is the type-token ratio. The distinction between a "type" and its "tokens" is "an ontological one between a general sort of thing and its particular concrete instances (to put it in an intuitive and preliminary way)" (Wetzel, 2018). Every text has its own TTR. From the values of TTR of these texts here, it displays that Trump's TTR is lower than Clinton's both in campaign speeches and debates. As a result, a general conclusion can be reached that Trump's language is not as rich as Clinton's.

\subsubsection{H-Point}

The $h$-point originated from the number " $h$ index", which was proposed by Hirsch (2005). It is "defined as the number $h$ of papers with citation counts higher or equal to $h$ " (Popescu, 2007, p 555). Hirsch first used this index "as a particularly simple and useful way to characterize the scientific output of a researcher" $(2005$, p. 16569). He argued that " $h$ was preferable to other single-number criteria commonly used to evaluate scientific output of a researcher" (Hirsch, 2005, p. 16569). Under this circumstance, Popescu and his study brought "empirical arguments for the transfer of the $h$-index concept from scientometrics to linguistics" (2007, p. 556). He switched "the problem from paper citation ranking to word frequency ranking" (Popescu, 2007, p. 556). Accordingly, the " $h$-index for words" represents the "word distribution width" and is "defined as the number $h$ of unique words with counts higher or equal to $h$ " (Popescu, 2007, p. 557) instead of citations. In this study, the $h$-point in the above table is a threshold determined by the rank-frequency distribution of the texts.

When $r=f(r)$, the value of $r$ is the $h$-point ( $r$ represents the rank, and $f(r)$ represents the frequency of the words in that rank). The frequency of the words which are before the $h$-point is higher than their ranks. On the contrary, the frequency of the words which are after the $h$-point is lower than their ranks. If the $h$-point cannot be found directly from the rank-frequency distribution table, it will be calculated with the following formula (Liu, 2017):

$$
h=\frac{f\left(r_{1}\right) r_{2}-f\left(r_{2}\right) r_{1}}{r_{2}-r_{1}+f\left(r_{1}\right)-f\left(r_{2}\right)}
$$

(assuming the $h$-point is between $r_{l}$ and $r_{2}$, and $r_{2}>r_{l}$ )

Accordingly, in this study, the rank-frequency table of Clinton's speeches is shown in Table 3. 
Table 3. Part of the frequency list of Clinton's speeches

\begin{tabular}{llll}
\hline Rank & Word & Frequency & $\%$ \\
\hline$\ldots$ & $\ldots$ & $\ldots$ & $\ldots$ \\
$\mathbf{7 9}$ & believe & 82 & 0.212 \\
$\mathbf{8 0}$ & how & $\mathbf{8 1}$ & 0.209 \\
$\mathbf{8 1}$ & like & $\mathbf{8 0}$ & 0.207 \\
$\mathbf{8 2}$ & Americans & 80 & 0.207 \\
$\mathbf{8 3}$ & let & 79 & 0.204 \\
$\mathbf{8 4}$ & jobs & 78 & 0.201 \\
$\ldots$ & $\ldots$ & $\ldots$ & $\ldots$ \\
\hline
\end{tabular}

Therefore, the $h$-point of Clinton's speeches should be calculated as follows:

$$
h=\frac{81 * 81-80 * 80}{81-80+81-80}=80.5
$$

The words before the $h$-point are more likely to be function words which may have a higher frequency, and the words after the $h$-point are more likely to be content words (Liu, 2017). As a result, the value of the $h$-point will reflect the richness of the text. The richness of texts is also shown in Table 2 in the form of $R_{l}$.

\subsection{3 $R_{1}$}

$R_{I}$ means the vocabulary richness of the texts which can particularly reflect one's language style. The value of $R_{I}$ is related to the $h$-point. The formula is shown as follows:

$$
\begin{gathered}
R_{I}=1-\underline{\mathrm{F}(h)} \\
\underline{\mathrm{F}(h)}=\mathrm{F}(h)-\frac{h^{2}}{2 N} \\
\text { So, } R_{l}=1-\left[\mathrm{F}(h)-\frac{h^{2}}{2 N}\right]
\end{gathered}
$$

Through the formula above, for instance, $R_{l}$ of Trump's debates can be calculated as follows:

$$
R_{l}=1-\left[\sum_{h=1}^{65} f(h)-\frac{65^{2}}{2 * 23190}\right] \approx 0.531
$$

By that analogy, the rest of the values of $R_{I}$ can be calculated. By comparing the values of $R_{I}$ in texts of these two candidates in Table 2, it is surprising to see that $R_{I}$ of Trump is higher than that of Clinton in campaign speeches. In debates, however, $R_{I}$ of Trump is lower than that of Clinton. Since one's impromptu speech, to some extent, can reflect one's mind better for the lack of full preparation, this study prefers to use the value of $R_{l}$ in debates to illustrate their vocabulary richness.

From the analysis all above, it can be concluded that Trump's vocabulary richness is lower than Clinton's from a general perspective.

\subsection{Pronouns in the Speeches}

As far as pronouns are concerned, Clinton used the pronoun you more often than Trump in her election speeches. The word you appeared altogether 528 times in her speeches and ranked 13 in the keyword list. According to Pennebaker, "pronouns reflect where people are paying attention" (2011, p. 100). Therefore, speakers who use you "are looking at or thinking about their audience" (2011, p. 100), which means that they want to make a connection with the audience. Thus, the pronoun you is used to appeal to the audience. In the case of election speeches, the frequent use of you makes the public feel that their interests are being considered by a potential country leader who has the power to make a difference to their life. In Clinton's speeches, she was likely to create unfair pictures of ordinary people living a hard life against the rich making huge profits to indicate that America needed change. The following is an example of you being used in the way that it can connect and appeal to the audience- the voters.

Example 1

You worked extra shifts, took second jobs, postponed home repairs... you figured out how to make it work. 
You see corporations making record profits, with CEOs making record pay, but your paychecks have barely budged.

While many of you are working multiple jobs to make ends meet, you see the top 25 hedge fund managers making more than all of America's kindergarten teachers combined. And, often paying a lower tax rate.

(Hillary Clinton's Campaign Launch Speech, Note 1)

By letting the audience imagine the huge gap between ordinary hardworking citizens and the rich who possess a large fortune, Clinton underlined the unfair tax system in the country. Naturally, she offered herself as the right person to do the job - to change America and to make it a better place and a fairer country for more ordinary people to live in. In this way, the audience might be infected by her, agree with her, and in the end vote for her, which exactly suited Clinton's purpose of her speeches.

Another interpretation of you is that it implies the speaker's relatively higher social status. As is stated by James W. Pennebaker, "the pronouns $I$, we, and you are by far the words that consistently reveal status" and that "the person who uses more second-person pronouns like you and your is likely to be the person higher in status" (2011, p. 100). As a democrat, Hillary Clinton represents the elite in the United States, which explains her use of you in a different way. Apart from applying you to shorten the distance between her and the audience as mentioned above, she also applied you in a way that the pronoun showed her superiority and relatively higher social status - no matter she used it in this way consciously or unconsciously. Here is an example as such.

\section{Example 2}

And you're lucky I didn't try singing that, too, I'll tell you!

......

And I want you to remember this, because to me, this is absolutely the most-compelling argument why we should do this.

(Hillary Clinton's Campaign Launch Speech, Note 1)

In the example above, the pronoun you was used as a symbol of giving orders. It indicated that Hillary Clinton seemed to "order" the audience to do what she wanted them to. Besides, throughout the speeches, she kept reminding the audience that she was once the First Lady, a Senator and the Secretary of State. Altogether, "First Lady", "Senator" and "Sectary of State" which refer to Clinton herself have a word frequency of 3, 10 and 12 respectively in the ten speeches selected. By mentioning her time in office, indeed, she wanted to make sure that the audience knew about her hard work and her contributions to the country. Nevertheless, it also suggested that she had more power than the audience. With dissatisfaction with the current state bureaucracy among working-class American voters (Lamont, Park, \& Ayala-Hurtado, 2017), anti-elitism became increasingly popular. As a result, being a member among the elite was no longer an advantage for Clinton. Tired of the unchanged American society under the control of the elite, ordinary people and working-class citizens in America asked for a change- a change for a better future for themselves instead of the elite. The elite had enjoyed too much superiority and priority. It was time that the ordinary American citizens' voice be heard. As a consequence, Donald Trump, who displayed himself nothing like a traditional politician from the elite group, stimulated the passionate participation of the silent majority in the election in the way of defying the Establishment in American politics (Parmar, 2017). By catering for the sentiment of the ordinary voters, Trump managed to win the support, the will, and eventually, the votes of a large number of working-class American people. As is shown above, two different ways of applying you in the election speeches led to two opposite results. One helped Clinton draw the audience to her side, making them believe that she would run the country with their interests in mind. The other, however, widened the distance between Clinton and her audience, doing no good to her campaign, which instead contributed to the popularity of Trump to some extent.

In addition to their difference in the use of the pronoun you, a similarity between the two candidates can be found in terms of the pronoun we. They both used we on a frequent basis in their speeches. The word we both ranked the second in the keyword lists of Clinton's and Trump's speeches with a word frequency of 750 and 722 respectively. As in the case of the pronoun you, the frequent use of the word we indicates a higher status of the speaker as well (Kacewicz, Pennebaker, Davis, Jeon, \& Graesser, 2014). As politicians, Clinton and Trump have more resources and power than the ordinary people in the United States. Therefore, it can be said that they are in a higher position in the social hierarchy. Nevertheless, the phenomenon of a higher frequency in the use of the pronoun we reflects "the fact that high-status individuals are more collectively oriented or other-oriented" (Kacewicz et al., 2014, p. 137). It means that their attention is more focused on others, which makes sense in that politicians like Clinton and Trump needed to rely on the people of the country voting for them in the election. 
Therefore, it is typical of politicians to be inclined to talk about protecting the interests of as many groups of people as possible in their speeches.

The pronoun we actually refers to at least five different meanings: "the you-and-I we", "the my-friends-and-not-you $w e$ ", "the we-as-you $w e$ ", "the we-as-I $w e$ " and "the every-like-minded-person-on-earth $w e$ " (Note 2) (Pennebaker, 2011, p. 101). Among the five meanings, politicians tend to use the last one, which "is the vaguest of all" (Pennebaker, 2011, p. 101). When looking at the left side of the word we, it can be seen that several words-“America/American(s)", "country/countries", "future", "job(s)", "people" and "together"- appeared frequently (word frequency $\geq 3$ ) both in the speeches of Clinton and Trump (See Table 4).

Table 4. Word frequency for collocations of we

\begin{tabular}{lll}
\hline & Clinton's speeches & Trump's speeches \\
\cline { 2 - 3 } Collocations of we & Word frequency $(\geq 3)$ & \\
\hline America/American(s) & 9 & 5 \\
country/countries & 5 & 9 \\
future & 6 & 6 \\
job(s) & 4 & 6 \\
people & 3 & 6 \\
together & 9 & 9 \\
\hline
\end{tabular}

The above figures show that both Clinton and Trump attempted to narrow the distance between the audience and them by addressing speeches that were about creating a better "future" for the "country" and for the "American" "people". Since employment is the foundation of people's livelihood, Clinton and Trump also laid much emphasis on "jobs" in their speeches. For a special purpose of appealing to the audience and to raise their confidence about the future of the country, the two politicians underlined the importance of all the people doing their part "together" to make America great again. In order to realize this goal, the first step, naturally, was to vote for them. They created beautiful dreams with sweet fruit in their speeches, making promises to meet the needs and to protect the interests of the people. In this way, the high spirits in their speeches became infectious, persuading the audience to vote for them. Based on this, the purpose of the election campaign could be achieved. In all, by taking advantage of the pronoun we, both Clinton and Trump attempted to draw the audience- the potential voters - to their own side so that they could earn more votes in the election.

\subsection{Debate Strategies}

\subsubsection{Interrupting for Power}

Language is functional, and accordingly, people will use it to achieve both personal and political ends. To some extent, language is always related to political activities. Partington (2002) argued that language is not merely a tool for politicians to achieve some goals, but it can go further that politics is language.

The issue of impoliteness has drawn much attention in previous studies of discourse in political debates. Jaworski and Galasinski (2000) found that a debate which aimed at power would contribute to a positive self-presentation and an inevitable negative depiction of the other. As a result, there must be a relationship between impoliteness and power. In the political debates selected for the research, impoliteness did exist in the form of frequent interruptions.

Interruption happens frequently in daily life. It can be defined as an action that somebody breaks others' turn to speak in order to take over the conversation. West and Zimmerman also defined it as a deep "intrusion into the internal structure of a speaker's utterance" (1977, p. 523). Previous studies have indicated that language can be manipulated to demonstrate power. In this study, the competitive relationship between the two presidential candidates (at that time) left them with no choice but to manipulate their language to attack each other for the aim of supporting their own opinions and showing their superiority in the presidential debates.

By using the software Antconc, the statistics about the interrupting words can be seen in Table 5 below.

Table 5. Frequency of "Excuse me"

\begin{tabular}{lll}
\hline & Clinton & Trump \\
\hline Frequency of the interrupting phrase "Excuse me" & 0 & 14 \\
\hline
\end{tabular}


As is seen, "Excuse me" occurred 14 times in Trump's debates, which means an apparent interruption in the conversation during the debates. Nevertheless, Clinton never used this phrase in their debates, which was a significant difference from Trump. In the final debate, for instance, the host reminded Trump many times that his time was up, and that he should stop talking. Nonetheless, it made no difference.

Example 3

WALLACE: Sir, your two minutes are up.

WALLACE: Sir... (interrupted by Trump)

WALLACE: Time, Mr. Trump.

WALLACE: Wait, but...

WALLACE: Mr. Trump... (more than one time)

WALLACE: Well, let me - wait, wait, sir, let me...

WALLACE: Sir, if I may finish my question... Time.

WALLACE: Well, no, sir, because we're running out of time...

Sacks, Schegloff, and Jefferson argued that "the organization of taking turns to speak is fundamental to conversation" (1974, p. 696). For a host, a good way to guarantee "the smooth flow of conversation" (Nor, 2012, p. 130) in a show is to control the discourse by appropriately using discourse markers for speaking turns. While it should be noted that Wallace used many of these markers to remind Trump of the timing in the debates, unfortunately, it did not work for Trump. In contrast, there was barely any turn-taking marker used by Wallace for Clinton. Some previous experimental studies have pinpointed that "the occurrence of interruptions is clustered in a few conversations for the same-sex pairs, while almost uniformly distributed across cross-sex pairs" (Zimmerman \& West, 1996, p. 225). In their experiment, a class of female speakers' rights to speak seemed to be "casually infringed upon by males" (Zimmerman \& West, 1996, p. 225). And thus, it was concluded that the distribution of turns to speak in conversation might reflect the differences between males and females in the economic system, which indicated the existence of male-dominance in society (Zimmerman \& West, 1996). This kind of male-dominance is also demonstrated through males interrupting females in conversation to gain control under the underlying male-dominance mind. As is seen, Trump's frequent interruptions were exactly in accord with the above descriptions.

Besides continuing to speak directly regardless of the host's reminding, Trump also "politely" interrupted.

Example 4

TRUMP: Excuse me. My turn. You were very much involved in every aspect of this country. Very much. And you do have experience. I say the one thing you have over me is experience, but it's bad experience, because what you've done has turned out badly.

TRUMP: Excuse me. She just went about 25 seconds over her time. Could I just respond to this, please?

From the above example, it can be seen that there was a different time standard for Trump. For one thing, it seemed to be fatal for him to bear others' taking up his time. For another thing, he freely prolonged his own speeches and did not feel guilty for his interruption. 


\subsubsection{Strategy of Repetition}

Table 6. Keyword list of the debates

\begin{tabular}{|c|c|c|c|c|c|c|c|}
\hline \multicolumn{4}{|c|}{ Clinton } & \multicolumn{4}{|c|}{ Trump } \\
\hline Rank & Freq & Keyness & Word & Rank & Freq & Keyness & Word \\
\hline 1 & 85 & 789.578 & donald & 1 & 469 & 930.456 & we \\
\hline 2 & 568 & 760.386 & $\mathrm{i}$ & 2 & 679 & 854.439 & $\mathrm{i}$ \\
\hline 3 & 368 & 723.46 & we & 3 & 540 & 735.249 & you \\
\hline 4 & 139 & 334.543 & our & 4 & 41 & 718.582 & obama \\
\hline 5 & 497 & 310.92 & that & 5 & 213 & 688.132 & re \\
\hline 6 & 24 & 257.79 & trump & 6 & 52 & 634.024 & hillary \\
\hline 7 & 106 & 255.134 & think & 7 & 177 & 604.213 & going \\
\hline 8 & 93 & 226.749 & ve & 8 & 43 & 518.405 & isis \\
\hline 9 & 77 & 200.254 & want & 9 & 118 & 420.746 & country \\
\hline 10 & 67 & 197.671 & country & 10 & 366 & 403.352 & have \\
\hline 11 & 11 & 191.066 & obama & 11 & 26 & 381.624 & mosul \\
\hline 12 & 53 & 189.845 & president & 12 & 256 & 345.619 & $\mathrm{t}$ \\
\hline 13 & 10 & 183.844 & putin & 13 & 47 & 343.593 & clinton \\
\hline 14 & 100 & 179.527 & because & 14 & 154 & 336.147 & our \\
\hline 15 & 76 & 175.455 & going & 15 & 316 & 334.966 & they \\
\hline 16 & 107 & 165.138 & people & 16 & 104 & 283.015 & look \\
\hline 17 & 15 & 157.65 & isis & 17 & 142 & 282.967 & because \\
\hline 18 & 37 & 153.314 & jobs & 18 & 153 & 279.211 & very \\
\hline 19 & 48 & 141.346 & lot & 19 & 268 & 271.789 & she \\
\hline 20 & 210 & 140.545 & have & 20 & 15 & 268.815 & putin \\
\hline 21 & 111 & 136.655 & do & 21 & 495 & 237.309 & it \\
\hline 22 & 131 & 134.698 & what & 22 & 12 & 215.052 & obamacare \\
\hline 23 & 93 & 127.868 & well & 23 & 137 & 214.774 & people \\
\hline 24 & 117 & 120.479 & about & 24 & 34 & 209.616 & percent \\
\hline 25 & 9 & 110.434 & undocumented & 25 & 395 & 193.148 & $\mathrm{~s}$ \\
\hline 26 & 221 & 106.219 & you & 26 & 29 & 186.143 & tremendous \\
\hline 27 & 73 & 105.055 & know & 27 & 17 & 177.928 & trillion \\
\hline 28 & 28 & 96.098 & america & 28 & 31 & 176.555 & disaster \\
\hline 29 & 62 & 92.988 & re & 29 & 89 & 174.875 & ve \\
\hline 30 & 15 & 91.87 & wealthy & 30 & 34 & 169.862 & russia \\
\hline
\end{tabular}

As is seen in Table 6 above, generally speaking, the frequency of each keyword of Clinton was lower than that of Trump. It means that Trump was more likely to repeat his words for the purpose of emphasis or a lack of vocabulary.

In addition to the keywords of the specific topic that the host gave to them, their differences on wording can also be seen. For instance, the keyness of "tremendous" in Trump's debates is 186.143, and he used the word 29 times to express the meaning of greatness. On the contrary, Clinton was more likely to use different words to express the same meaning. Although Clinton's strategy made her look more "well-educated", Trump's strategy of repetition actually made his speech more impressive. Though Trump might not use the strategy on purpose, it still exerted a powerful effect on highlighting messages he wanted to convey to the audience.

\section{Conclusion}

Combining quantitative analysis with the qualitative method of CDA, this study aims to compare language features of the two 2016 US election candidates-Donald Trump and Hillary Clinton-from a general perspective as well as in detail. Statistics and figures illustrate the overall results while details in their transcripts of speeches and debates demonstrate their specific differences in the choice of words and strategies.

From a general view, it can be concluded that Clinton's vocabulary is richer than Trump's in that Clinton's value of $R_{l}$ in debates is higher than that of Trump. In the meantime, under a detailed observation, this study offers some insights into these two candidates' language styles. In campaign speeches, Clinton used the pronoun you much more often than Trump. On one hand, the use of you narrowed the distance between Clinton and her audience. On the other hand, it also implied Clinton's higher social status and her attempts of widening the gap between the audience and her. Donald Trump, however, by demonstrating himself nothing like a traditional 
politician, won himself the support of a large number of voters. Besides the difference, Clinton and Trump both used the pronoun we on a regular basis, showing to the audience that they had the people's interests in mind. Therefore, the distance between the speakers and the audience was shortened, helping Clinton and Trump in getting more votes from the audience. In the debates, Trump's repetitive use of the same words and his frequent interruptions showed his desire for power under the influence of a male-dominance mind. Nevertheless, his strategy of repetition actually made his speech in the debates more impressive.

At the same time, there are some limitations about this study. First, the corpus of this study is not large enough to generate more convincing results. Secondly, the results of quantitative analysis, to some extent, may not be well explained. In addition, more statistical software could have been used to achieve a more thorough and reliable result. Beyond that, some factors, such as ghostwriters for speech writing and the ability of improvisation, have not been taken into account in the study.

\section{Acknowledgments}

This study is supported by the National Natural Science Foundation of China (Project Nos. 71872165; 71402163), the Social Science and Humanities Research Foundation of Chinese Ministry of Education (Project No. 18YJC630241), and the Research Foundation of China's Language Commission (Project No. YB135-95). All views expressed are those of the authors and not of the sponsoring organizations.

\section{References}

Abbas, A. H. (2019). Super-hyperbolic man: hyperbole as an ideological discourse strategy in Trump's speeches. International Journal for the Semiotics of Law, 32(2), 505-522. https://doi.org/10.1007/s11196-019-09621-8

Ainsworth, S., \& Hardy, C. (2004). Critical discourse analysis and identity: why bother? Critical Discourse Studies, 1(2), 225-259. https://doi.org/10.1080/1740590042000302085

Alagözlü, N., \& Sahin, S. (2011). Silence as a multi-purpose speech act in Turkish political discourse. Procedia Social and Behavioral Sciences, 15, 3008-3013. https://doi.org/10.1016/j.sbspro.2011.04.233

Alemi, M., Latifi, A., \& Nematzadeh, A. (2018). Persuasion in political discourse: Barak Obama's presidential speeches against ISIS. Russian Journal of Linguistics, 22(2), 278-291. https://doi.org/10.22363/2312-9182-2018-22-2-278-291

Benoit, W. L., \& Sheafer, T. (2006). Functional theory and political discourse: televised debates in Israel and the United States. Journalism \& Mass Communication Quarterly, 83(2), 281-297. https://doi.org/10.1177/107769900608300204

Bock, J., Byrd-Craven, J., \& Burkley, M. (2017). The role of sexism in voting in the 2016 presidential election. Personality and Individual Differences, 119, 189-193. https://doi.org/10.1016/j.paid.2017.07.026

Borriello, A. (2017). 'There is no alternative': How Italian and Spanish leaders' discourse obscured the political nature of austerity. Discourse \& Society, 28(3), 241-261. https://doi.org/10.1177/0957926516687419

Bracic, A., Israel-Trummel, M., \& Shortle, A. F. (2019). Is sexism for white people? Gender stereotypes, race, and the 2016 presidential election. Political Behavior, 41(2), 281-307. https://doi.org/10.1007/s11109-018-9446-8

Carreon, J. R., \& Svetanant, C. (2017). What Lies Underneath a Political Speech?: Critical Discourse Analysis of Thai PM's Political Speeches Aired on the TV Programme Returning Happiness to the People. Open Linguistics, 3(1), 638-655. https://doi.org/10.1515/opli-2017-0032

Chilton, P. (2017). Toward a neuro-cognitive model of socio-political discourse, and an application to the populist discourse of Donald Trump. Langage et société, 160-161(2), 237. https://doi.org/10.3917/1s.160.0237

Demata, M. (2017). “A great and beautiful wall”: Donald Trump's populist discourse on immigration. Journal of Language Aggression and Conflict, 5(2), 274-294. https://doi.org/10.1075/jlac.5.2.06dem

Dicu, G. (2018). Linguistic practices in gendered institutional settings: speech behavior of female political leaders. Journal of Research in Gender Studies, 8(1), 158-164. https://doi.org/10.22381/JRGS8120188

Edward, Hutahaean, S., Kurniawan, \& Hamuddin, B. (2018). Language and power in presidential speech campaign discourse: Donald Trump vs. Hillary Clinton. IOP Conference Series: Earth and Environmental Science, 175, 012082. https://doi.org/10.1088/1755-1315/175/1/012082

Ernst, N., Esser, F., Blassnig, S., \& Engesser, S. (2019). Favorable opportunity structures for populist communication: Comparing different types of politicians and issues in social media, television and the press. 
The International Journal of Press/Politics, 24(2), 165-188. https://doi.org/10.1177/1940161218819430

Fairclough, N. (2001). The discourse of New Labour: Critical discourse analysis. In M. Wetherell, S. Taylor \& S. J. Yates (Eds.), Discourse as data: A guide for analysis (pp. 229-266). London: Sage.

Franco, M. (2016). Clinton, Trump and the Catholic church. Survival, 58(6), 43-47. https://doi.org/10.1080/00396338.2016.1257178

Ghazal, A. N. (2019). Exploring charismatic leadership: A comparative analysis of the rhetoric of Hillary Clinton and Donald Trump in the 2016 presidential election: charisma and rhetoric. Presidential Studies Quarterly, 49(1), 56-74. https://doi.org/10.1111/psq.12490

Grebelsky-Lichtman, T., \& Katz, R. (2019). When a man debates a woman: Trump vs. Clinton in the first mixed gender presidential debates. Journal of Gender Studies, 28(6), 699-719. https://doi.org/10.1080/09589236.2019.1566890

Hardy, J. (2008). Stratification of environmental education and education for sustainable development in Australia: an analysis of positions vacant advertisements. Environmental Education Research, 14(2), 165174. https://doi.org/10.1080/13504620801951699

Hirsch, J. E. (2005). An index to quantify an individual's scientific research output. Proceedings of the National Academy of Sciences of the United States of America, 102(46), 16569-16572. https://doi.org/10.1073/pnas.0507655102

Jacobsen, R. R. (2019). Interruptions and co-construction in the First 2016 Trump-Clinton US presidential debate. Journal of Pragmatics, 148, 71-87. https://doi.org/10.1016/j.pragma.2019.05.019

Jaworski, A., \& Galasinski, D. (2000). Unilateral norm breaking in a presidential debate: Lech Walesa versus Aleksander Kwasniewski. Research on Language and Social Interaction, 33(3), 321-345. https://doi.org/10.1207/S15327973RLSI3303_4

Kacewicz, E., Pennebaker, J. W., Davis, M., Jeon, M., \& Graesser, A. C. (2014). Pronoun use reflects standings in social hierarchies. Journal of Language and Social Psychology, 33(2), 125-143. https://doi.org/10.1177/0261927X13502654

Kelsey, E. (2003). Constructing the public: implications of the discourse of international environmental agreements on conceptions of education and public participation. Environmental Education Research, 9(4), 403-427. https://doi.org/10.1080/1350462032000126087

Lajevardi, N., \& Abrajano, M. (2019). How negative sentiment toward Muslim Americans predicts support for Trump in the 2016 presidential election. The Journal of Politics, 81(1), 296-302. https://doi.org/10.1086/700001

Lamont, M., Park, B. Y., \& Ayala - Hurtado, E. (2017). Trump's electoral speeches and his appeal to the American white working class. The British Journal of Sociology, 68, S153-S180.

Linkeviciute, V. (2019). Conceptual metaphors in Donald Trump's political discourse: Politics domain (2018). Studies About Languages, 34, 46-55. https://doi.org/10.5755/j01.sal.0.34.21886

Liu, D., \& Lei, L. (2018). The appeal to political sentiment: An analysis of Donald Trump's and Hillary Clinton's speech themes and discourse strategies in the 2016 US presidential election. Discourse, Context \& Media, 25, 143-152. https://doi.org/10.1016/j.dcm.2018.05.001

Liu, H. T. (2017). An introduction to quantitative linguistics (1st ed.). Beijing: The Commercial Press.

Major, B., Blodorn, A., \& Major Blascovich, G. (2018). The threat of increasing diversity: Why many White Americans support Trump in the 2016 presidential election. Group Processes \& Intergroup Relations, 21(6), 931-940. https://doi.org/10.1177/1368430216677304

Monnat, S. M., \& Brown, D. L. (2017). More than a rural revolt: Landscapes of despair and the 2016 presidential election. Journal of Rural Studies, 55, 227-236. https://doi.org/10.1016/j.jrurstud.2017.08.010

Montgomery, M. (2017). Post-truth politics?: Authenticity, populism and the electoral discourses of Donald Trump. Journal of Language and Politics, 16(4), 619-639. https://doi.org/10.1075/jlp.17023.mon

Nuolijärvi, P., \& Tiittula, L. (2011). Irony in political television debates. Journal of Pragmatics, 43(2), 572-587. https://doi.org/10.1016/j.pragma.2010.01.019

Parmar, I. (2017). Elites and American power in an era of anti-elitism. International Politics, 54(3), 255-259. https://doi.org/10.1057/s41311-017-0036-x 
Partington, A. (2002). The linguistics of political argument: the spin-doctor and the wolf-pack at the White House (1st ed.). London: Routledge. https://doi.org/10.4324/9780203218259

Pennebaker, J. M. (2011). The secret life of pronouns. New York, NY: Bloomsbury Press. https://doi.org/10.1016/S0262-4079(11)62167-2

Petlyuchenko, N., \& Charnyakova, V. (2019). Features of expressive female speech in the political discourse of Spain and Latin America. Advanced Education, 6(12), 212-219. https://doi.org/10.20535/2410-8286.155500

Philpot, T. S. (2018). Race, gender, and the 2016 presidential election. PS: Political Science \& Politics, 51(4), 755-761. https://doi.org/10.1017/S1049096518000896

Ponomarenko, E. B., Vasilkova, N. N., Volskaya, N. N., Kasperova, L. T., \& Nikolaeva, A. V. (2018). Female political media discourse in American and English linguocultures: Speech strategies and tactics. XLinguae, 11(2), 625-638. https://doi.org/10.18355/XL.2018.11.02.50

Popescu, I.-I. (2007). Text ranking by the weight of highly frequent words. In P. Grzybek \& R. Kohler (Eds.), Exact methods in the study of language and text. Dedicated to Gabriel Altmann on the occasion of his 75th birthday (pp. 555-566). Berlin: Mouton de Gruyter. https://doi.org/10.1515/9783110894219.555

Quam, J., \& Ryshina-Pankova, M. (2016). "Let me tell you...”: Audience engagement strategies in the campaign speeches of Trump, Clinton, and Sanders. Russian Journal of Linguistics, 20(4), 140-160. https://doi.org/10.22363/2312-9182-2016-20-4-140-160

Ricks, J. I. (2018). The effect of language on political appeal: Results from a survey experiment in Thailand. Political Behavior, 1-22. https://doi.org/10.1007/s11109-018-9487-z

Sacks, H., Schegloff, E. A., \& Jefferson, G. (1974). A simplest systematics for the organization of turn-taking for conversation. Language, 50(4), 696-735. https://doi.org/10.1353/lan.1974.0010

Savoy, J. (2018). Trump's and Clinton's Style and Rhetoric during the 2016 Presidential Election. Journal of Quantitative Linguistics, 25(2), 168-189. https://doi.org/10.1080/09296174.2017.1349358

Schoor, C. (2017). In the theater of political style: Touches of populism, pluralism and elitism in speeches of politicians. Discourse \& Society, 28(6), 657-676. https://doi.org/10.1177/0957926517721082

Sharififar, M., \& Rahimi, E. (2015). Critical discourse analysis of political speeches: A case study of Obama's and Rouhani's speeches at UN. Theory and Practice in Language Studies, 5(2), 343. https://doi.org/10.17507/tpls.0502.14

Shockley-Zalabak, P. S., Morreale, S. P., \& Stavrositu, C. (2019). Voters' perceptions of trust in 2016 presidential candidates, Clinton and Trump: Exploring the election's outcome. American Behavioral Scientist, 63(7), 856-887. https://doi.org/10.1177/0002764217730855

Sriwimon, L., \& Zilli, P. J. (2017). Applying critical discourse analysis as a conceptual framework for investigating gender stereotypes in political media discourse. Kasetsart Journal of Social Sciences, 38(2), 136-142. https://doi.org/10.1016/j.kjss.2016.04.004

Tenorio, E. H. (2002). 'I want to be a prime minister', or what linguistic choice can do for campaigning politicians. Language and Literature, 11(3), 243-261. https://doi.org/10.1177/096394700201100304

Terrill, R. E. (2017). the post-racial and post-ethical discourse of Donald J. Trump. Rhetoric and Public Affairs, 20(3), 493. https://doi.org/10.14321/rhetpublaffa.20.3.0493

Törnberg, A., \& Törnberg, P. (2016). Muslims in social media discourse: Combining topic modeling and critical discourse analysis. Discourse, Context \& Media, 13, 132-142. https://doi.org/10.1016/j.dcm.2016.04.003

van Dijk, T. A. (2015). Critical discourse analysis. In D. Tannen, H. E. Hamilton \& D. Schiffrin (Eds.), The handbook of discourse analysis (2nd ed., pp. 466-485). Hoboken: John Wiley \& Sons. https://doi.org/10.1002/9781118584194.ch22

Vasvári, L. O. (2013). Gendered hate speech and political discourse in recent U.S. elections and in post socialist Hungary. CLCWeb: Comparative Literature and Culture, 15(4). https://doi.org/10.7771/1481-4374.2303

Waikar, P. (2018). Reading Islamophobia in hegemonic neoliberalism through a discourse analysis of Donald Trump's narratives. Journal of Muslim Minority Affairs, 38(2), 153-178. https://doi.org/10.1080/13602004.2018.1466490

Wang, Y., \& Liu, H. (2018). Is Trump always rambling like a fourth-grade student? An analysis of stylistic features of Donald Trump's political discourse during the 2016 election. Discourse \& Society, 29(3), 299- 
323. https://doi.org/10.1177/0957926517734659

West, C. D., \& Zimmerman, D. H. (1977). Women's place in everyday talk: reflections on parent-child interaction. Social Problems, 24(5), 521-529. https://doi.org/10.2307/800122

Wetzel, L. (2018). Types and tokens. In E. N. Zalta (Ed.), The Stanford Encyclopedia of Philosophy (Fall 2018 ed.). California: Metaphysics Research Lab, Stanford University.

Whitehead, A. L., Perry, S. L., \& Baker, J. O. (2018). Make America Christian again: Christian nationalism and voting for Donald Trump in the 2016 presidential election. Sociology of Religion, 79(2), 147-171. https://doi.org/10.1093/socrel/srx070

Wilson, J. (2015). Critical discourse analysis. In D. Tannen, H. E. Hamilton \& D. Schiffrin (Eds.), The handbook of discourse analysis (2nd ed., pp. 775-794). Hoboken: John Wiley \& Sons. https://doi.org/10.1002/9781118584194.ch36

Zimmerman, D. H., \& West, C. (1996). Sex roles, interruptions and silences in conversation. In R. Singh (Ed.) Towards a Critical Sociolinguistics (pp. 211-235). Amsterdam: John Benjamins. https://doi.org/10.1075/cilt.125.12zim

\section{Notes}

Note 1. The examples are extracted from Hillary Clinton's Campaign Launch Speech on June 13, 2015.

Note 2. A more detailed explanation for the five meanings of the pronoun we can be seen in Chapter 7 of James W. Pennebaker's book The Secret Life of Pronouns.

\section{Appendix A}

\section{List of the Sampled Speeches and Debates}

Table A1. Clinton's campaign speeches and debates

\begin{tabular}{|c|c|c|c|c|}
\hline Rank & Words & Date & Theme & URL \\
\hline \multicolumn{5}{|c|}{ Campaign speeches } \\
\hline 1 & 4747 & 13 June, 2015 & $\begin{array}{l}\text { Hillary Clinton's } \\
\text { campaign launch speech }\end{array}$ & $\begin{array}{l}\text { http://time.com/3920332/transcript-full-text-hillary-clinton-campa } \\
\text { ign-launch/ }\end{array}$ \\
\hline 2 & 1702 & $\begin{array}{l}27 \text { February, } \\
2016\end{array}$ & $\begin{array}{l}\text { Hillary Clinton's South } \\
\text { Carolina speech }\end{array}$ & $\begin{array}{l}\text { https://www.dailykos.com/stories/2016/2/27/1492599/\%13Hillary } \\
\text { \%13Clinton\%13s\%13South\%13Carolina\%13speech\%13Transcri } \\
\text { pt }\end{array}$ \\
\hline 3 & 1314 & $1 \mathrm{March}, 2016$ & $\begin{array}{l}\text { Hillary Clinton's Super } \\
\text { Tuesday victory speech }\end{array}$ & $\begin{array}{l}\text { http://time.com/4244178/super-tuesday-hillary-clinton-victory-sp } \\
\text { eech-transcript-full-text/ }\end{array}$ \\
\hline 4 & 4250 & 2 June, 2016 & $\begin{array}{l}\text { Hillary Clinton's speech } \\
\text { on Donald Trump and } \\
\text { national security }\end{array}$ & $\begin{array}{l}\text { http://time.com/4355797/hillary-clinton-donald-trump-foreign-pol } \\
\text { icy-speech-transcript/ }\end{array}$ \\
\hline 5 & 5596 & 28 July, 2016 & $\begin{array}{l}\text { Hillary Clinton's } \\
\text { acceptance speech }\end{array}$ & $\begin{array}{l}\text { https://www.bloomberg.com/news/features/2016-07-29/hillary-cli } \\
\text { nton-s-acceptance-speech-annotated }\end{array}$ \\
\hline 6 & 5895 & $\begin{array}{l}11 \text { August, } \\
2016\end{array}$ & $\begin{array}{l}\text { Hillary Clinton's } \\
\text { economic speech }\end{array}$ & $\begin{array}{l}\text { https://www.newsweek.com/hillary-clinton-full-transcript-econo } \\
\text { mic-speech-48960257 }\end{array}$ \\
\hline 7 & 2937 & $\begin{array}{l}25 \text { August, } \\
2016\end{array}$ & $\begin{array}{l}\text { Hillary Clinton's speech } \\
\text { on the alt-right }\end{array}$ & $\begin{array}{l}\text { https://www.huffingtonpost.com/entry/hillary-clinton-speech-text } \\
\text { _us_57bf4575e4b02673444f2307 }\end{array}$ \\
\hline 8 & 6150 & $\begin{array}{l}6 \text { September, } \\
2016\end{array}$ & $\begin{array}{l}\text { Hillary Clinton's stump } \\
\text { speech }\end{array}$ & $\begin{array}{l}\text { https://www.npr.org/2016/09/15/493924325/inside-hillary-clinton } \\
\text { s-stump-speech-annotated }\end{array}$ \\
\hline 9 & 4834 & $\begin{array}{l}10 \text { October, } \\
2016\end{array}$ & $\begin{array}{l}\text { Hillary Clinton's speech } \\
\text { at Ohio State }\end{array}$ & $\begin{array}{l}\text { https://www.dispatch.com/content/stories/local/2016/10/11/hillar } \\
\text { y-clintons-speech-at-ohio-state.html }\end{array}$ \\
\hline 10 & 1098 & $\begin{array}{l}9 \text { November, } \\
2016\end{array}$ & $\begin{array}{l}\text { Hillary Clinton's } \\
\text { concession speech }\end{array}$ & $\begin{array}{l}\text { https://www.telegraph.co.uk/news/2016/11/09/hillary-clintons-sp } \\
\text { eech-in-full/ }\end{array}$ \\
\hline \multicolumn{5}{|r|}{ 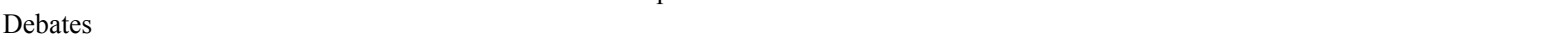 } \\
\hline 1 & 4782 & $\begin{array}{l}27 \text { September, } \\
2016\end{array}$ & First debate & $\begin{array}{l}\text { https://www.boston.com/news/politics/2016/09/28/read-the-full-tr } \\
\text { anscript-of-the-presidential-debate-here }\end{array}$ \\
\hline 2 & 6347 & $\begin{array}{l}10 \text { October, } \\
2016\end{array}$ & Second debate & $\begin{array}{l}\text { https://www.nytimes.com/2016/10/10/us/politics/transcript-secon } \\
\text { d-debate.html }\end{array}$ \\
\hline 3 & 7116 & $\begin{array}{l}19 \text { October, } \\
2016\end{array}$ & Final debate & $\begin{array}{l}\text { https://www.washingtonpost.com/news/the-fix/wp/2016/10/19/th } \\
\text { e-final-trump-clinton-debate-transcript-annotated/?noredirect=on } \\
\text { \&utm_term=.f94e } 1 \text { b27714c }\end{array}$ \\
\hline
\end{tabular}


Table A2. Trump's campaign speeches and debates

\begin{tabular}{|c|c|c|c|c|}
\hline Rank & Words & Date & Theme & URL \\
\hline \multicolumn{5}{|c|}{ Campaign speeches } \\
\hline 1 & 2342 & 21 March, 2016 & $\begin{array}{l}\text { Full text of Donald Trump's } \\
\text { speech to AIPAC }\end{array}$ & $\begin{array}{l}\text { https://www.timesofisrael.com/donald-trumps-full-speech } \\
\text {-to-aipac/ }\end{array}$ \\
\hline 2 & 3496 & 27 April, 2016 & $\begin{array}{l}\text { Donald Trump's foreign } \\
\text { policy speech }\end{array}$ & $\begin{array}{l}\text { http://www.thefiscaltimes.com/2016/04/28/Transcript-Do } \\
\text { nald-Trump-s-Foreign-Policy-Speech-April-27-2016 }\end{array}$ \\
\hline 3 & 6339 & 16 June, 2016 & $\begin{array}{l}\text { Donald Trump's presidential } \\
\text { announcement speech }\end{array}$ & $\begin{array}{l}\text { http://ime.com/3923128/donald\%13trump\%13announce } \\
\text { ment } \% 13 \text { speech/ }\end{array}$ \\
\hline 4 & 5143 & 21 July, 2016 & $\begin{array}{l}\text { Full transcript of Donald } \\
\text { Trump's acceptance speech } \\
\text { at the RNC }\end{array}$ & $\begin{array}{l}\text { https://www.vox.com/2016/7/21/12253426/donald-trump- } \\
\text { acceptance-speech-transcript-republican-nomination-trans } \\
\text { cript }\end{array}$ \\
\hline 5 & 3549 & 8 August, 2016 & $\begin{array}{l}\text { Donald Trump's economic } \\
\text { speech }\end{array}$ & $\begin{array}{l}\text { https://www.washingtonpost.com/news/the-fix/wp/2016/0 } \\
\text { 8/08/donald-trumps-economic-speech-annotated/ }\end{array}$ \\
\hline 6 & 2886 & $\begin{array}{l}16 \text { August, } \\
2016\end{array}$ & $\begin{array}{l}\text { READ: Full transcript of } \\
\text { Donald Trump law \& } \\
\text { order speech }\end{array}$ & $\begin{array}{l}\text { https://heavy.com/news } / 2016 / 08 / \text { read-full-transcript-donal } \\
\text { d-trump-transcript-law-and-order-speech-west-bend-wisc } \\
\text { onsin }\end{array}$ \\
\hline 7 & 3531 & $\begin{array}{l}18 \text { August, } \\
2016\end{array}$ & $\begin{array}{l}\text { Donald Trump's best speech } \\
\text { of the } 2016 \text { campaign, } \\
\text { annotated }\end{array}$ & $\begin{array}{l}\text { https://www.washingtonpost.com/news/the-fix/wp/2016/0 } \\
\text { 8/19/donald-trumps-best-speech-of-the-2016-campaign-an } \\
\text { notated/?utm_term=.3902f4958668 }\end{array}$ \\
\hline 8 & 6849 & $\begin{array}{l}31 \text { August, } \\
2016\end{array}$ & $\begin{array}{l}\text { Transcript: Donald Trump's } \\
\text { full immigration speech, } \\
\text { annotated }\end{array}$ & $\begin{array}{l}\text { https://www.latimes.com/politics/la-na-pol-donald-trump- } \\
\text { immigration-speech-transcript-20160831-snap-htmlstory. } \\
\text { html }\end{array}$ \\
\hline 9 & 2363 & $\begin{array}{l}7 \text { September, } \\
2016\end{array}$ & $\begin{array}{l}\text { Donald Trump's speech on } \\
\text { national security in } \\
\text { Philadelphia }\end{array}$ & $\begin{array}{l}\text { https://thehill.com/blogs/pundits-blog/campaign/294817-t } \\
\text { ranscript-of-donald-trumps-speech-on-national-security-in }\end{array}$ \\
\hline 10 & 1616 & $\begin{array}{l}9 \text { November, } \\
2016\end{array}$ & $\begin{array}{l}\text { Donald Trump's victory } \\
\text { speech }\end{array}$ & $\begin{array}{l}\text { https://www.cnn.com/2016/11/09/politics/donald-trump-v } \\
\text { ictory-speech/index.html }\end{array}$ \\
\hline \multicolumn{5}{|r|}{$\int_{1}$} \\
\hline 1 & 8504 & $\begin{array}{l}27 \text { September, } \\
2016\end{array}$ & First debate & $\begin{array}{l}\text { https://www.boston.com/news/politics/2016/09/28/read-th } \\
\text { e-full-transcript-of-the-presidential-debate-here }\end{array}$ \\
\hline 2 & 7315 & $\begin{array}{l}10 \text { October, } \\
2016\end{array}$ & Second debate & $\begin{array}{l}\text { https://www.nytimes.com/2016/10/10/us/politics/transcrip } \\
\text { t-second-debate.html }\end{array}$ \\
\hline 3 & 6499 & $\begin{array}{l}19 \text { October, } \\
2016\end{array}$ & Final debate & $\begin{array}{l}\text { https://www.washingtonpost.com/news/the-fix/wp/2016/1 } \\
\text { 0/19/the-final-trump-clinton-debate-transcript-annotated/? } \\
\text { noredirect=on\&utm_term=.f94e } 1 \text { b27714c }\end{array}$ \\
\hline
\end{tabular}

\section{Copyrights}

Copyright for this article is retained by the author, with first publication rights granted to the journal.

This is an open-access article distributed under the terms and conditions of the Creative Commons Attribution license (http://creativecommons.org/licenses/by/4.0/). 